\title{
O Auto dos 99\% - O Centro Popular de Cultura da União Nacional dos Estudantes (CPC da UNE) e a mobilização estudantil
}

Eduardo Luís Campos Lima ${ }^{1}$

RESUMO: O presente artigo traz uma análise da peça "Auto dos Noventa e Nove Por Cento", escrita por integrantes do Centro Popular de Cultura da União Nacional dos Estudantes (CPC da UNE) em 1962, procurando examinar a natureza épica do texto em relação com a conjuntura política.

ABSTRACT: This article analises the play "Auto dos Noventa e Nove Por Cento", produced by Centro Popular de Cultura da União Nacional dos Estudantes (CPC da UNE) in 1962, examining mainly its epic form in relation to the political moment.

PALAVRAS-CHAVE: Teatro épico, Bertolt Brecht, Erwin Piscator

KEYWORDS: Epic theater, Bertolt Brecht, Erwin Piscator

A década de 1960 começa com um período de intensa mobilização da classe trabalhadora brasileira. No campo, impedidos de se organizar em sindicatos rurais e sem amparo de legislação trabalhista, os camponeses tentam conquistar seus direitos; crescem as Ligas Camponesas e outras entidades de luta. O I Congresso Nacional de Trabalhadores e Agricultores, realizado em 1961, tem como palavra de ordem a Reforma Agrária (MENDONÇA \& FONTES, 1996, p.7-20). Nas cidades, a erosão dos ganhos reais dos operários pela inflação demonstra um "aumento da taxa de exploração do trabalho" (OLIVEIRA, 1972, p.45); multiplicam-se as greves em diversos segmentos da economia e, paralelamente, os sindicatos exigem "maior participação nas grandes questões nacionais" (MENDONÇA \& FONTES, 1996, p.17). As massas trabalhadoras urbanas denunciam o pacto populista, cuja ruptura tinha como reflexo, na esfera

1 Mestrando do Programa de Estudos Lingüísticos e Literários em Inglês da FFFLCH/USP. Título da pesquisa: A forma épica em Injunction Granted, do Federal Theatre Project, e em Teatro Jornal: Primeira Edição, do Teatro de Arena 
institucional, os rearranjos partidários no Legislativo, com a formação de frentes interpartidárias (MENDONÇA \& FONTES, p. 13) e o posterior rompimento da aliança entre PSD e PTB.

A polarização das forças políticas e o ascenso do operariado têm desdobramentos entre estudantes e intelectuais. A esquerda universitária havia conseguido, desde 1957, garantir o controle da União Nacional dos Estudantes (UNE). Em 1960, uma greve dos estudantes de Salvador demonstra que havia uma crise na universidade brasileira (FÁVERO, 1995, p.29). A discussão sobre a necessidade de amplas transformações na educação ganha cada vez mais peso com a politização crescente dos estudantes e o fortalecimento da UNE, que relaciona a luta pela Reforma Universitária à mobilização, crescente no país, pelas reformas de base.

$\mathrm{Na}$ esfera artística, a fusão do Teatro de Arena com o Teatro Paulista do Estudante (TPE), formado principalmente por quadros do Partido Comunista Brasileiro (PCB) - como Oduvaldo Vianna Filho e Gianfrancesco Guarnieri -, no fim dos anos 1950, resulta no surgimento de uma dramaturgia nacional e preocupada com questões sociais, algo, até então, inédito. Um passo adiante é dado quando Chico de Assis e Vianinha decidem deixar o Arena, em 1961, para articular um novo coletivo de trabalho, cujo foco fosse produzir arte para um público de trabalhadores. Dessa iniciativa surge o Centro Popular de Cultura (CPC).

\section{UNE Volante e CPC}

O CPC surgiu, principalmente, a partir da aglutinação das pessoas que se envolveram na produção e nos ensaios da peça A mais-valia vai acabar, seu Edgar, de Vianinha. Carlos Estevam Martins, que foi o primeiro presidente da entidade, relata:

Nós percebemos que tínhamos que inventar uma iniciativa qualquer, que conseguisse manter todo mundo integrado $\mathrm{e}$ convivendo, e depois ver o que dava para fazer. (...) Então, assim, de repente, surgiu a ideia: vamos dar um curso de História da Filosofia!" (BARCELLOS, 1994, p.75).

O curso, que seria ministrado pelo professor José Américo Motta Pessanha, ocorreu na UNE, instituição à qual os fundadores do CPC bateram às portas à procura de novas articulações e de uma estrutura física que amparasse minimamente as atividades. 
Naquele momento - em 1961 - setores de esquerda da Juventude Universitária Católica (JUC) haviam obtido a hegemonia entre os estudantes, em uma frente com o PCB. O jucista Aldo Arantes tornou-se presidente da UNE. A esquerda católica vivia um momento de transição; atritos com a hierarquia da Igreja e uma polarização com setores reacionários da JUC apontavam para a necessidade de formar uma organização autônoma (RIDENTI, 2002, pp. 213-282). A composição com o PCB que levou à conquista do controle da UNE era outro risco; nas palavras de Herbert de Souza, a nova diretoria sabia que, "se ficasse sozinha na Praia do Flamengo (onde ficava a sede da UNE), seria fatalmente engolida pela experiência e pela máquina do PC" (BARCELLOS, 1994, p. 251). É nesse contexto que surge, no começo de 1962, a Ação Popular (AP). A realização da UNE Volante viria a solucionar todas essas questões.

Organizada pela primeira vez em 1962, a UNE Volante contou com vinte membros do CPC e cinco dirigentes da UNE, que viajaram por todo o país, tratando de mobilizar a massa estudantil e promover discussões a respeito da Reforma Universitária. Palestras, seminários e debates eram acompanhados pela apresentação de peças e filmes do CPC. A turnê seria fundamental para a expansão da UNE, servindo para o estabelecimento de vínculos com as uniões estaduais de estudantes e para aumentar a base de universitários mobilizados no Brasil inteiro; da AP, que nascera pouco antes e, com as viagens, articulava-se nacionalmente; e do CPC, que disseminaria diversos centros regionais pelo Brasil inteiro.

Fortalecidos pelo mesmo esforço, CPC e AP certamente desenvolveram, naquele momento, um intercâmbio de ideias e práticas. Embora a iniciativa de militantes do PCB tenha sido determinante para a criação do CPC, é sabido que, entre seus ativistas, havia militantes de outras correntes de esquerda, pessoas sem vínculo com nenhuma organização (caso de Ferreira Gullar, que só aderiu ao PCB em 1964), e também católicos. Cacá Diegues, por exemplo, relata que trabalhou na articulação "da esquerda católica dentro do CPC'(idem, ibidem, p.41). Observa-se, portanto, que diferentes grupamentos convergiriam para constituir o CPC - e a UNE Volante seria um momento-chave para os cepecistas.

\section{Seminário de Reforma Universitária e o Auto dos $99 \%$}

A UNE Volante teve como ponto de partida o II Seminário Nacional de Reforma Universitária (SNRU), em Curitiba, em março de 1962. A primeira edição do Seminário 
havia sido realizada em Salvador, no ano anterior, e suas conclusões haviam sido publicadas na Declaração da Bahia (FÁVERO, 1995, Anexos I e II) .

As conclusões do II SNRU foram publicadas em um documento batizado de Carta do Paraná, assinado pelo presidente Aldo Arantes e pelo vice-presidente de Assuntos Educacionais da UNE, Marco Aurélio Garcia. A leitura da Carta e da Declaração da Bahia (que postulam uma visão semelhante da universidade brasileira e da necessidade da reforma) mostra que o Auto dos 99\%, peça apresentada pelo CPC da UNE no II SNRU e ao longo da primeira UNE Volante, bebeu das ideias expostas nos dois documentos.

Segundo conta Carlos Estevam Martins, o Auto dos 99\% havia sido produzido com urgência; apenas o texto havia sido preparado previamente:

Lembro-me que, na primeira UNE Volante, nós fizemos o primeiro ensaio de texto em público. Nós levamos o texto, só que nunca tínhamos ensaiado. Então a nossa apresentação foi ensaio mesmo. Foi com papel na mão, todo mundo lendo. [...]

Foi o 99\%, num teatro de Curitiba, o Teatro Guaíra. Mas, era muita folga. Você chega, o pessoal pagando para ver o espetáculo, e você diz: 'O espetáculo não está pronto, nós vamos montar no caminho. Vocês deram o azar de serem a primeira cidade. Então, nós vamos ler o texto aqui. (BARCELLOS, 1994, p.86)

O II SNRU ocorreu, como aponta a Carta do Paraná, entre 17 e 24 de março. O Auto dos 99\% já estava sendo apresentado no dia 19 de março (CALDAS, Ano, p.83). A peça, portanto, foi escrita antes da conclusão do II SNRU e da divulgação da Carta do Paraná. O cruzamento das datas e a similitude das visões expostas pela Carta e pela peça indicam que os ativistas do CPC já estavam em profundo contato com os dirigentes da UNE mesmo antes de ocorrer a UNE Volante, chegando a uma comunhão de ideias e a uma interpretação comum dos problemas da universidade brasileira. A afirmação pode parecer uma obviedade, mas ganha relevo quando lembramos que CPC e UNE eram entidades autônomas, apesar de sua vinculação institucional, e vez ou outra, ocorriam atritos entre elas. Entre os seis autores do Auto, estava o já citado Marco Aurélio Garcia, que personificou a aliança entre CPC e UNE na produção da peça.

Notar as convergências entre peça e documentos não é algo de pouca importância, uma vez que a leitura da realidade brasileira exposta pela UNE nos documentos (com reverberação no Auto) difere, em alguns aspectos, do pecebismo, apontando outras idéias que marcariam a produção do CPC. 


\section{Breve análise da peça}

O Auto dos $99 \%$ foi criado como parte da campanha pela Reforma Universitária, devendo servir de suporte às atividades mobilizadoras da massa estudantil em diversas regiões do Brasil. Trata-se, portanto, de uma peça de agitação e propaganda. Os autores da peça (seis, ao todo: Armando Costa, Carlos Estevam Martins, Cecil Thiré, Antonio Carlos da Fontoura, Marco Aurélio Garcia e Oduvaldo Vianna Filho) já estavam familiarizados com os elementos do teatro épico; Vianinha provinha do Arena, onde participou, como ator e autor, de peças que apresentavam uma dramaturgia epicizante. O grupo que deu origem ao CPC, além disso, reuniu-se em torno da produção de $A$ mais-valia vai acabar, seu Edgar, como já foi dito; na peça de Vianinha destacam-se, claramente, elementos empregados nos teatros dos alemães Erwin Piscator e Bertolt Brecht. No Auto, cuja intenção era informar, denunciar e mobilizar, a forma épica não poderia ser desprezada. Os autores, de fato, optam por uma dramaturgia predominantemente épica, em que se misturam, novamente, propostas piscatorianas e brechtianas, como se verá a seguir.

A peça dedica toda sua primeira metade a uma reconstituição da história da universidade no país - reconstituição que acaba abarcando a história do Brasil como um todo. A retomada da história, desde as origens pré-coloniais, para situar e problematizar uma questão atual, segundo a professora Iná Camargo Costa, era uma marca dos anos 1960 (COSTA, 1994, p. 116); de fato, uma reconstrução da história do Brasil e da universidade brasileira aparece nos dois documentos finais dos seminários pela Reforma Universitária. A Declaração da Bahia, por exemplo, assinala: “O Brasil, dentro do contexto internacional, de colônia portuguesa passou para a dominação econômica imposta de início pela Inglaterra, e, logo a seguir, pelos Estados Unidos da América do Norte, sob a qual permanece até hoje, apesar de sua ilusória independência política" (UNE, 1961, p. X).

É precisamente o caráter de ilusão ou de mentira da história oficial que se procura apontar no recurso à revisão histórica. Ao jogar por terra as visões grandiloquentes sobre o passado, o alvo é, obviamente, desmistificar também a visão construída sobre o presente. Mais à frente, aparece na mesma Declaração da Bahia: “A democracia que existe no nosso país é evidentemente uma farsa. Basta dizer que 52\% de nossa população não possui o direito de participar na política diretiva da nação, não 
tendo incentivo algum à educação e ao progresso". O recurso a procedimentos de desmontagem ideológica, típico do marxismo - que se disseminava entre os estudantes com a crescente politização do movimento de universitários - é também o núcleo da teoria brechtiana2. A ideia da formação do Brasil (e de suas frágeis instituições) como um encadeamento de improvisos escamoteados perpassa todo o Auto.

Assim, a peça começa com um prólogo, em que uma Voz fala sobre o Brasil précabralino, um "imenso Brasil, gordo Brasil, sumarento Brasil, a jurar um brasileiro salomônico, cristalino, carregado de abraços e sorrisos e calma e paixão e verdade. Um povo a semear verdade e riso." Desde o início, a Voz declara, ironicamente, tratar-se de uma peça "imbuída de doce e nacional lirismo".

Mas... eis que... Eis que... Oh! Eis que então... oh!... então, cá chegaram os portugueses. E então... Então começou o pega-pra-capar. Começou a nossa história do "salve-se-quem-puder". Começou a história do Brasil, que já foi história de todo o mundo, de tudo quanto é país grande, de tudo quanto é baronete, condessa, peralvilho, mandrião que se espalharam pelos séculos.

História que já foi de todos, de todos, menos do Brasil. Brasil seco, mirrado, de costela de fora, de pires na mão. (COSTA et al, 1962, p. 104)

A história oficial, mistificadora, é ridicularizada por meio do "choque" que a Voz expressa ao revelar a causa primeira dos problemas nacionais e pela contraposição entre a linguagem empolada e expressões cotidianas, como "pega-pra-capar" (COSTA et al., p. 104). Desde o início, a história do Brasil é uma história de profundas contradições, de domínio pelo grande capital internacional - mas também por potências de segundo escalão, os "baronetes, condessas, peralvilhos e mandriões" - e de nenhuma autodeterminação (COSTA et al., p. 104). Fica claro, desde o prólogo, que os alvos da peça são o imperialismo e a ideologia que lhe dá sustentação.

Até aí, já foi possível identificar elementos típicos do teatro épico, como a própria inclusão do prólogo e de um narrador, que introduz os quadros seguintes -

2 Conforme esclarece o professor Roberto Schwarz, o anti-ilusionismo é uma das marcas principais do teatro de Bertolt Brecht; escancaram-se os procedimentos de teatralização, no lugar de escondê-los, para que o "público se dê conta do caráter construído das figuras e, por extensão, do caráter construído da realidade que elas imitam e interpretam" (SCHWARZ, 1999, p. 114). Os mecanismos de distanciamento com que Brecht opera, prossegue Schwarz, aproximam-se da ideia marxista de "desnaturalização"; "ao contrário dos economistas, que viam na divisão da sociedade em classes a expressão acabada da natureza humana, Marx a explicava com uma formação história" (Id., ibid., p. 115). 
procedimentos característicos de Brecht. O uso copioso da sátira e de referências conjunturais (a Voz diz que o passarinho pipilante da época idealizada no início do prólogo agora é vendido na Casa da Banha como se fosse frango; a água que abundava foi escondida por Carlos Lacerda) demonstra que outra referência importante é o teatro de revista, cuja forma já havia sido explorada na montagem de A mais-valia...

A Voz anuncia que se vai operar uma reconstrução histórica ("Vamos começar da época em que tudo era verde") (COSTA et al., p. 104); a seguir entram em cena dois índios. Um deles obteve sucesso na caçada; o outro não. Imediatamente, eles repartem tudo em porções iguais, enquanto entoam uma breve canção, que diz que quem "divide comida, a vida encomprida" (COSTA et al., p. 105). Trata-se aí de uma situação exemplar: intocados pelas contradições da economia mercantil e vivendo em comunismo primitivo, os indígenas vivem em solidariedade. As desigualdades existentes no seio das sociedades ditas tradicionais dão lugar a uma idealização de suas relações sociais. Não se trata, entretanto, de uma idealização do mesmo tipo que a operada pela história oficial; a ideia é contrastar aquela solidariedade com a concorrência da economia mercantil (COSTA, 1994, p. 116) - cujos tentáculos aparecem logo a seguir.

Surgem os portugueses, repentinamente, e começa um novo quadro. Desde o início ridicularizados como o português das piadas, eles fazem tudo de improviso; mas logo declaram que seu interesse é obter rendimentos nas novas terras - o que vai ser "mole", como diz Caminha, "posto que é terra em que plantando tudo dá e os nativos levam os cornos mais trouxas que meus olhos já tiveram oportunidade de ver" (COSTA et al., p. 106). Na sequência de quadros seguinte, desdobra-se a cooptação dos indígenas pelos portugueses, na figura do jesuíta. A princípio figurando como massa indistinta na composição de um Coro, os índios passam, pouco a pouco, à individuação (Índios 1, 2, 3 e 4), na medida em que a economia mercantil vai sendo introduzida em sua sociedade pelos conquistadores. Os diferentes interesses que passam a dividir o coro indígena, inicialmente coeso, delineiam individualidades em oposição, o que se traduz em personagens variadas.

Valendo-se de astúcia, o padre ganha a confiança dos índios, que o aclamam como Tupã, e logo os seduz com suas bugigangas. Os colares coloridos com que presenteia os índios são prontamente absorvidos, juntamente com a caricatura de latim que ele fala: "Bugiganga. Bugigangorum. Ih!, que legal, meu! Que legal! Bonito às pampas! Bugiganga" (COSTA et al., p. 107). A interpolação de gíria típica da época em 
que a peça foi escrita parece fazer a ligação dos índios do período pré-colonial com a classe trabalhadora contemporânea. A relação é demarcada novamente na canção que comenta o quadro: "Bugiganga, bugigangorum/ Índio quer bugiganga/ Mesmo que continue de tanga/ Parece que será essa história do Brasil/ Cheio de bugiganga/ Sempre de tanga" (COSTA et al., p. 107).

Após dar os presentes, o jesuíta anuncia que há uma contrapartida: os índios devem trabalhar "em coisa dignificante de homini" (COSTA et al., p. 107). Se os indígenas consistem em uma figuração da classe trabalhadora contemporânea, o padre também passa a representar a elite brasileira. $\mathrm{O}$ fato de a economia mercantil ser introduzida por um doutrinador, como o jesuíta, mostra que a intenção é aproximar intelectuais e capitalistas como figuras-chaves do mesmo processo de dominação econômica e cultural. Essa ideia aparece também na Carta do Paraná, em que se afirma que, nos estágios iniciais da colonização, “a cultura não representava ainda senão uma maneira erudita de os jesuítas doutrinarem uma população rarefeita", com o objetivo de "fundamentar as bases da economia colonial" (UNE, 1962, p. LI). No Auto, entretanto, esse ponto de vista é desenvolvido até as últimas consequências.

O padre faz os indígenas cortarem pau-brasil; já transformado em administrador da exploração madeireira, cede os instrumentos de trabalho para cada um, machadinhos, que tira de dentro de um bolso enorme - o que indica que sua missão evangelizadora incluía, de maneira planejada, a empresa mercantil. Depois, recompensa o Índio 1, que trabalhou de maneira mais correta, dando-lhe mais colares. Os outros reagem: "Quem está trabalhando é índio.[...] Um pagamento só" (COSTA et al., p. 108). A organização social dos índios torna-os capazes de questionar a lógica mercantilista - da mesma forma que a posição social dos trabalhadores contemporâneos possibilita a tomada de consciência. "Non senhoribus. Essa essere onda de comunistorum. Mi paga para quem trabalhorum maisorum", retruca o padre (COSTA et al., p. 108). Completa-se a imagem de dominação econômica com auxílio ideológico da religião.

A partir daí, as divisões entre os índios crescem cada vez mais. Com a entrada do novo personagem, o capitão donatário - a quem o padre anuncia que "os índios estão domesticados [...] são todos fãs da Rádio Nacional" (COSTA et al., p. 109) - começa o pagamento em farinha (findo o trabalho ideológico, não é mais preciso o ornamento da cultura). Quando os índios descobrem que o pagamento foi reduzido à metade, já que "o preço do transporte aumentou", pedem para rachar o pagamento, como de costume, mas dessa vez o Índio 1 recusa: "Mas, que rachar? Rachar era no tempo em que a gente era 
selvagem." O donatário, que marca o ritmo de trabalho dos índios continuamente, caçoa:

Façam como ele (Aponta Índio 1.) Tem as melhores bugigangas do país. Porque sabe trabalhar. Obedece à marcação. Vão se danar, ó, nativos! Vão se danar! Não tem mais caça. Água acabou. Nós derrubamos muitas árvores, ó, bocós da mola! Acabou árvore, acabou água, acabou bicho. Vão se danar, ó, nudistas! É melhor trabalhar comigo, ó, precursores dos nordestinos! (COSTA et al., p. 110)

O donatário, na transposição para a década de 1960, figura como o capitalista industrial, já que faz referência ao ritmo de trabalho fabril. Esse vínculo entre capitão donatário e industrial moderno é significativo, já que indica a ligação entre modernização, dominação estrangeira e o que há de mais retrógrado na história nacional. A revelação desse vínculo, na medida em que problematiza a industrialização, parece consistir em uma posição à esquerda daquela de teóricos como Nelson Werneck Sodré, para quem o "atraso brasileiro" decorria da "aliança do imperialismo com o latifúndio que, internamente, redunda na preservação de formas atrasadas de produção e de relações de produção pré-capitalistas na agricultura" (OLIVEIRA FILHO, 2000, p. 17). Uma posição semelhante já aparecia na Declaração da Bahia: "Constata-se que o sistema sulino incrementa a sua taxa de crescimento às custas mesmo do subdesenvolvimento nordestino"(UNE, 1961, p. VII).

O Índio 1, operário-padrão, é transformado em feitor. O padre e o donatário o apontam como "precursor de Eugênio Gudin e Gustavo Corção" e chamam-no, em outro trecho, de "Augusto Frederico Schmidt de tanga" (COSTA et al., p. 111) referências a três intelectuais conservadores muito ativos nos jornais da época, que representavam, cada um, uma vertente diferente do conservadorismo brasileiro (o primeiro, de viés liberal, o segundo, de viés católico, e o terceiro, de viés desenvolvimentista). A cooptação completa do Índio 1, que chega a afirmar que "índio não é gente", é comentada pelo Coro, que indica que todas aquelas vertentes conservadoras brasileiras acabariam desaguando naquela que, de acordo com os autores, é a pior de todas: a de Carlos Lacerda (COSTA et al., p. 112).

A recitação de declinações de latim pelos índios, puxada pelo padre, acompanha vários momentos dessa sequência de quadros, lado a lado com o processo de cooptação, exploração e esgotamento dos índios pela economia mercantil. A lição de latim e a 
prece católica, que ajudam a marcar o ritmo do trabalho dos índios, contrapõem-se, na cena, às gestualidades marcantes de cada fase, funcionando como instrumento adicional de crítica - e remete ao assunto primordial da peça, a Reforma Universitária. O modelo exploratório entra em crise e o donatário aponta a rede intrincada da economia mercantil em que o Brasil foi envolvido: "Gastamos um dinheirão, eles pouco produzem, a Inglaterra a nos comer as vesículas" (COSTA et al., p. 112). Decide empregar mão de obra africana e o ciclo se repete, dessa vez tendo o Índio 1 como doutrinador e feitor. Um "Cháu" brusco do coro de escravos encerra o quadro, dando a entender que o movimento continuaria.

A desmistificação da história oficial, por meio da revelação das motivações econômicas que estão por trás da missão jesuítica no Brasil, faz com que essa primeira unidade da peça seja a que mais se relaciona às formulações de Brecht. Apresenta-se o desenvolvimento de cada fase do processo de dominação, problematizando, até o limite, as consequências sociais da introdução da economia mercantil, por meio de situações exemplares e personagens tipificados, contrapostos uns aos outros a partir de sua posição social. Mas nota-se o esforço de ressaltar, a cada momento, a reflexão e a crítica que devem ser alcançadas pelo público, preocupação que se traduz na alusão frequente a figuras e a situações contemporâneas. Desse esforço surge o elemento da sátira política e a introdução de procedimentos do teatro de revista - o que remete às propostas de Piscator. Na parte seguinte da peça, são precisamente os elementos mais ligados à revista política que emergem com mais força.

A sequência posterior marca uma série de saltos históricos, que levam a peça das origens do Brasil até a metade do século 20 e introduzem a temática da universidade propriamente dita. A sequência de episódios constrói um panorama de exemplos: cada um dos pequenos quadros expõe um momento de transição histórica - em que a mudança, como a Independência e a República, sempre pega a elite dirigente de surpresa, deixando-a confusa, furiosa ou simplesmente apática - e um vestibular fraudulento, que privilegia apenas as camadas superiores da sociedade. O Coro, que delimita o ponto de vista da classe trabalhadora, continuamente mostra-se esperançoso e depois frustrado em suas expectativas.

O Coro canta que D. João VI "criou escolas, abriu portos, ora bolas, e até a faculdade pros fidalgos inventou", apenas para "alegrar a sua vida" (COSTA et al., p. 114). O primeiro vestibular, aclamado pelo Coro como uma promessa de libertação, é decidido por uma prova de títulos, na qual é calorosamente aprovado o candidato que se 
declara cidadão português (dando a entender que, nesse momento, a elite brasileira confunde-se totalmente com a portuguesa). A seguir, a Independência, que, de acordo com o Coro, seria capaz de acabar com a "indecência de só passar português" (COSTA et al., p. 115), é declarada por um D. Pedro I furioso, sentado no penico. O vestibular, novamente decidido na prova de títulos, seleciona o aluno que se apresenta como "Barão de Caçapava" (COSTA et al., p. 116). O Coro, então, expõe sua expectativa de que, com a República, "vai chegar a vez do pobre" (COSTA et al., p. 116). Mas entra em cena um Marechal Deodoro que nem sabe o que é a República que está na iminência de proclamar. A esperada mudança, obviamente, não vem, e o Professor anuncia: "Patati, patatá, a República foi proclamada, patatá, tatá. Queiram declinar seus títulos" (COSTA et al., p. 116). Agora, é o "latifundiariozinho" o escolhido.

A última esperança do Coro é a chegada da máquina, quando o "progresso" vai precisar "não de anel de lata, não de título pra pendurar, mas de cabeça pra pensar" (COSTA et al., p. 117). Em cena, estão as promessas da industrialização brasileira, intensificada com o fim da República Velha - ciclo que continua até o momento em que a peça foi escrita. A conclusão, novamente, é desanimadora: agora, "todos podem fazer vestibular" - "todos que tiverem diploma de curso secundário..." (COSTA et al., p. 117). A exigência de curso secundário claramente restringe o acesso aos mais favorecidos; o aprovado se apresenta como "bacharel em Ciências e Letras e Desportos Miúdos pelo Ginásio Anglo-Franco-Portuga-Americano" (COSTA et al., p. 117). Ou seja, sucedem-se os segmentos dominantes no poder, mas continua sendo a elite a única camada da população que pode ingressar na faculdade. Tal elite, que nessa etapa apresenta-se como elite puramente econômica, é sempre ligada por laços íntimos à elite estrangeira, o que mostra que permanece sendo determinante o imperialismo a que o Brasil se encontra submetido. O conjunto se encerra com um comentário do Coro: "Então se abriu a faculdade/ para toda a humanidade/ para o Brasil e sua infelicidade!" (COSTA et al., p. 117). Às denúncias feitas anteriormente, soma-se um juízo crítico da história, o que remete, uma vez mais, às formulações de Piscator.

O Coro muda de posição e inicia um canto agitador, que sintetiza e reforça as denúncias feitas até então, informando que 57\% dos brasileiros são analfabetos, $67 \%$ não fizeram ginasial e $71 \%$ não fizeram científico, o que representa um total de $99 \%$ de brasileiros impedidos de ingressar na faculdade. "Logo, entra na faculdade/ Um por cento do povo brasileiro! Viva o um por cento! Viva o um por cento/ Do povo do Brasil! E o resto... e o resto... e o resto.../Vai ficar sem estudar..." (COSTA et al., p. 
118). A denúncia complementa o procedimento desmistificador, contrapondo a história oficial à crueza do dado estatístico: se houve uma missão civilizatória no país, que o colocaria no mesmo patamar da metrópole europeia, como pode o acesso à universidade estar impedido para $99 \%$ da população? Além disso, o dado numérico introduz o elemento factual em cena, aspecto típico do teatro político3.

Segue-se um conjunto de quadros que expõe a realidade da universidade no país naquele momento, iniciado por uma introdução musicada feita pelo Bedel e pelo Coro que costuram e comentam as cenas posteriores. A introdução apresenta uma prévia do que se verá adiante, mostrando um professor velhinho sendo retirado do sarcófago, para começar a aula, e soltando disparates sobre diferentes temas. O panorama seguinte expõe seis exemplos de cursos de ensino superior; em cena, aparecem trechos das aulas dadas pelos professores, sempre verbosas, pouco científicas e obsoletas, independentemente da disciplina. A divisão do panorama em episódios correspondentes, cada um, a um curso universitário, espelha a própria tradição do ensino superior no Brasil, organizado inicialmente em escolas superiores, completamente autônomas entre si, que depois seriam agregadas artificialmente nas universidades conglomeradas - sem perderem, no entanto, seu caráter de isolamento (FERNANDES, 2004, p. 273-316). Se funcionalmente os cursos são completamente estanques, na prática eles formam um todo unitário em sua obsolescência, em seu arcaísmo e em sua irrelevância para a sociedade. É isso o que o panorama apresenta.

A primeira aula, não por acaso, é de Ciências Sociais. O curso que, primordialmente, deveria conduzir a um conhecimento libertador - cumprindo assim a função que a UNE acredita que a universidade deveria desempenhar - acaba funcionando de maneira oposta. O exemplo sintetiza todas as questões que serão problematizadas nos outros quadros. Aparecem no discurso do Professor expressões consagradas na esfera jurídica, como "família, célula máter da sociedade" (COSTA et al., p. 120), o que demonstra que a crítica é a uma sociologia praticada pelos bacharéis

\footnotetext{
3 Uma das marcas do teatro operário, desde os primórdios, foi a avidez por representar a realidade da maneira mais direta possivel, com o fito de usar a encenação como arma para produzir denúncias. É possivel observar tal elemento nas formulações de Erwin Piscator, que buscava amplificar os "resultados propagandísticos" de seu teatro por meio de "uma metralha de exemplos", apresentados também por "estatística" (PISCATOR, 1968, p. 73). O procedimento obteve sua concretização máxima nos "jornais vivos", representações baseadas unicamente em notícias e disseminadas pela União Soviética, Europa Central e Estados Unidos nos anos 1920 e 1930, e em sua variação polonesa, a "faktomontaz" (montagem de fatos) (SIMALTY-TEMERSON, 1978, p. 193).
} 
em "ciências jurídicas e sociais", de fundamentação católica e conservadora. Dogmático e verboso, o discurso católico e os ataques ao marxismo que ele escamoteia dão lugar a um falatório inútil disfarçado de científico. Um aluno, com ar apalermado, leva a aula a sério, o que mostra que a irrelevância das discussões acadêmicas favorece a doutrinação dos mais desavisados. O Professor encerra com seu programa político, dizendo que classe social (conceito com o qual, em três anos de faculdade, talvez os alunos não tenham tido contato, segundo ele) "é um estado de espírito". Cabe à elite "uma atividade espiritual junto às camadas inferiores", para que o operário transforme-se, psicologicamente, "em homem da classe média e assim sucessivamente" (COSTA et al., p. 121).

A cena escurece para indicar corte para um outro quadro, que exibe as consequências da aula. Um Estudante vem para frente para falar com operários que surgem no palco, pedindo aumento. Mostra que aprendeu bem a lição, fazendo uma análise do problema social pelo ponto de vista moral (justamente o procedimento de intelectuais como Gustavo Corção, criticado na primeira parte da peça [PAULA, 2005]). O problema deles não seria a pobreza, mas a "desorganização" e a "falta de confiança". O discurso tão irreal do Estudante é confrontado com a pergunta nua e crua que o Operário refaz: "Vai aumentar o salário ou não, ó, papagaio?” O Estudante se vê forçado a abandonar a verborragia e apresenta a argumentação típica do burguês industrial, afirmando que "o custo de produção subiu muito" (COSTA et al., p. 122). O que se depreende é que os sociólogos apalermados que o curso forma são farsantes que se colocam diante do proletariado para desmobilizá-lo e iludi-lo. A surra que os operários, insatisfeitos, aplicam no Estudante aponta que, para os autores do Auto, o avanço do proletariado prometia, para um futuro próximo, grandes dissabores para a fração da pequena burguesia que não se aliasse a ele.

O Bedel anuncia, sempre antecipando algumas pistas críticas, cada uma das aulas seguintes. Na Arquitetura, a abordagem classicista e estetizante do Professor, que só se preocupa com a coluna jônica, impede que os alunos, após três anos de curso, saibam o que é uma favela. O Professor declara que os próprios favelados dão conta de fazer os barracos, sem interferência de arquitetos, portanto discutir o assunto seria perder tempo. Na aula de História, a historiografia tradicional é ridicularizada por meio do exagero da verbosidade e detalhismo improdutivo do Professor, que relaciona a Independência do Brasil aos mínimos aspectos envolvidos no dia de D. Pedro, como o fato de ele ter tomado chá de erva do bicho ou estar de cueca verde. Conclui, de maneira 
"moderna", que esses fatos talvez tenham influenciado na Independência, talvez não tenham. A conclusão "moderna" do Professor evidencia novamente que a crítica feita pela peça se volta ao arcaísmo da academia brasileira que procura se travestir de moderno - fazendo-o, entretanto, apenas na aparência. Na aula de Introdução à Ciência do Direito, o Professor mostra despreparo e falta de seriedade, não conseguindo nem expor o conceito de Direito, concluindo que se trata "dessa bagunça que tem por aí" (COSTA et al. , p. 124). A aula de Economia também não se parece propriamente com uma aula, já que o Professor se limita a aconselhar: "Sai por aí no meio da rua que nem um possesso e inventa, cria, bola, castiga o meio mais eficiente de lucrar" (COSTA et al., p. 125). A faculdade de Economia, mais do que as outras, parece colar-se irremediavelmente à estrutura dominante.

A aula de Filosofia, que encerra a sequência, recebe um tratamento especial, da mesma forma que a de Ciências Sociais. A canção do Bedel, que introduz o quadro, expõe alguns pontos de vista materialistas, que servem de baliza para a aula do Professor - cujo tema é a "existência do não-ser" (COSTA et al., p. 126). As frases iniciais do Professor fazem, aparentemente, uma salada de formulações da filosofia présocrática, não chegando a fazer sentido. O único sentido que se pode depreender é que a filosofia ensinada pelo Professor não tem relação alguma com a realidade. A tagarelice pretensamente erudita é posta em ridículo, mais uma vez. A palestra acaba num crescendo, em que o Professor vai interpondo exemplos de "quão impossível se torna a definição do ser": "onde viram, os senhores, o triângulo e o miriágono? E o poliedro? E o ângulo?" (COSTA et al., p. 126). Conclui, enlouquecido, que a aula não existe, ele não existe e os alunos não existem, causando um surto coletivo entre os estudantes, que "gritam, urram, latem", e vomitam frases aprendidas na faculdade, como "Galia est divisa in partes tres" (COSTA et al., p. 126). O conhecimento apreendido pelos alunos, fútil, obsoleto e mentiroso, contrapõe-se ao conhecimento libertador. O paradoxo é figurado por meio desse surto coletivo - apenas uma loucura generalizada pode explicar a situação da universidade brasileira. Um Estudante canta, para concluir o episódio: "Estamos todos em forma/ Pela reforma que não virá/ O reitor nos informa/ "Como reforma?/ Se Universidade não há?” (COSTA et al., p. 127).

O objetivo do panorama, portanto, era expor a debilidade da universidade no Brasil, que, funcionando como instituição de suporte ideológico para as elites, não seria verdadeiramente transformada por uma ação governamental. A Lei de Diretrizes e Bases da Educação Nacional, que fora aprovada poucos meses antes do II SNRU, foi 
condenada pelos estudantes como simples ratificação jurídica da situação vigente. Daí a descrença expressa nos versos do Estudante. A necessidade de mobilização para transformar a universidade, que o Auto procura deixar cada vez mais clara, tem seu grande estímulo no quadro que se segue, que marca outro momento agitador da peça. Um Coro de alunos, cujas denúncias e palavras de ordem são continuamente intercaladas pelas do Estudante, sumariza, reforça e radicaliza as denúncias feitas até então. Os professores com cátedra vitalícia, símbolos do privilégio da universidade, são acusados diretamente de falsários, elitistas e ignorantes. As denúncias são complementadas pelas pautas da Reforma Universitária; o Estudante canta: "Professor sem concurso, não pode dar curso" (COSTA et al., p. 128). O Coro une os juízos a respeito da universidade à obrigação de construir a aliança entre estudantes, operários e camponeses; lembra que a possibilidade material de estudo de que os universitários gozam tem origem na produção da classe trabalhadora. A agitação abre os olhos de um Estudante, que se propõe a mudar as coisas.

É esse estudante que, no quadro final da peça, invade a congregação em que os Velhinhos estão reunidos. Eles já haviam começado as deliberações quando ele chega: decidiram pela suspensão do contrato de um professor assistente que deu duas aulas mais do que o previsto sobre existencialismo e marxismo (lembrando que a universidade é lugar apenas de discussões estéreis e que nenhuma ameaça, por menor que seja, seria tolerada); recusaram-se a mudar o horário das aulas, a pedido do diretório dos estudantes, que queriam trabalhar em um movimento de alfabetização ("Para alfabetização existem as escolas por aí. Só não se alfabetiza quem não quer...” [COSTA et al. p. 131); e negaram pedido de verbas de uma comissão de professores novos para bolsas de estudo para alunos (as verbas já estavam destinadas à instalação de ar refrigerado nas salas de reunião e ao aumento dos salários deles mesmos).

Os exemplos são intercalados, a toda hora, com elementos cômicos; um dos Velhinhos, surdo, dorme sem parar; o outro, ao ouvir a palavra "estudantes", surpreende-se, esquecendo-se de que há alunos na universidade. Aprofundando as possibilidades de crítica, o humor também funciona, em seguida, como forma de quebrar a carga dramática elevada do diálogo entre o Estudante que invade a reunião e o Velho 1, que decide ouvi-lo. A tomada de consciência pelo Estudante resulta em um momento de explosão (algo que ocorre também em A mais-valia..., quando D4 revoltase e decide descobrir "por que é que existe lucro"); ele precisa canalizar a indignação no confronto direto com os Velhinhos da Congregação (que, aliás, já devia contar com a 
participação de estudantes, como tinha determinado a LDB [FÁVERO, 1995, p. 42]). Explica que as matérias ensinadas na universidade "não são verdadeiras, ou são mentidas ou são esquecidas ou são roubadas!" Exige que o escutem, diz que é necessário "mudar tudo", que veio "para ajudar" (COSTA et al., p. 132). O Velho 1 lembra que há enorme tradição na "casa", citando grandes figuras que lá estudaram no período imperial e na República Velha - fases anteriores ao período de industrialização mais acelerada, quando a obsolescência da universidade ainda não era, talvez, tão evidente.

As falas do Velho 1 apenas reiteram a visão que os estudantes têm dos professores como elitistas e antiquados. O Estudante faz reivindicações que pautam a Reforma; o professor rebate uma a uma, com um discurso arcaico que remete uma vez mais aos jesuítas ("esta sineta, por exemplo, serviu para que Anchieta chamasse os índios para a primeira aula e hoje chama vocês para ensinar os mesmos valores que naquela época eram defendidos pelos jesuítas" [COSTA et al., p. 132]). O Estudante promete "ir à forra", dizendo: "Abaixo a Universidade! Abaixo os velhos! [...] Há de haver alguém no Brasil que se interesse por nós! Esperem!” (COSTA et al., p. 134). O diálogo todo prossegue sem interrupções cômicas, o que demonstra que se trata de um momento que deve provocar identificação - ao personagem do Estudante, aos autores e à própria ideia de uma juventude transformadora, em contraposição ao arcaísmo, imobilismo e conservadorismo dos Velhinhos.

A indignação fizera com que ele tentasse mudar alguma coisa "dentro da ordem”. Os argumentos expostos pelo Velho 1 demonstraram que não seria esse o canal das transformações necessárias. Mas o Estudante acredita na aliança com operários e camponeses; a classe trabalhadora, acredita ele, apoiará sua luta por reformas. A fala procura situar, portanto, a luta estudantil dentro do quadro de ascenso da classe trabalhadora - mas se trata de uma aposta, já que a aliança ainda não havia se concretizado.

Em uma peça como o Auto dos 99\%, o CPC, cujo programa voltava-se às massas populares (BETTI, 1997, p. 146) (objetivo que, dada a brevidade da experiência, não chegou a ser amplamente realizado), encontra com o público que acabou sendo seu destinatário privilegiado, o estudante. A capacidade de mobilização que o CPC teve sobre esses jovens estudantes e artistas, de fato, parece significativa; a UNE Volante teve grande êxito e foi um marco para a disseminação da UNE, da AP e do CPC. 
A aliança com operários e camponeses, entretanto, não se concretizaria: antes disso, a luta pelas reformas cairia junto com Jango, representando duro golpe às esperanças revolucionárias dos estudantes e pondo fim brusco ao CPC. E a Reforma Universitária feita pelos militares em 1968, que segundo Florestan Fernandes não passou "de uma panaceia" e ficou "aquém das exigências da situação (mesmo em confronto com as implicações educacionais do novo padrão dependente de subdesenvolvimento)"(FERNANDES, 2004, p. 314), acabou representando uma transformação, em grande parte, apenas aparente.

\section{REFERÊNCIAS BIBLIOGRÁFICAS:}

BARCELLOS, Jalusa. CPC da UNE: uma história de paixão e consciência. Rio de Janeiro: Nova Fronteira, 1994.

BETTI, Maria Sílvia. Vianinha. São Paulo: Edusp, 1997.

CALDAS, Ana Carolina. Centro Popular de Cultura no Paraná (1959-1964). Encontros e desencontros entre arte, educação e política. Dissertação (Mestrado em Educação). Universidade Federal do Paraná, Curitiba, PR.

CAMACHO, Thimoteo. Cultura dos trabalhadores e crise política: estudo sobre o Centro Popular de Cultura do Sindicato dos Metalúrgicos de Santo André. Fundo de Cultura do Município de Santo André, 1999.

COSTA, Armando et al. Auto dos Noventa e Nove Por Cento. In: PEIXOTO, Fernando (Org.). O melhor teatro do CPC da UNE. São Paulo: Global, 1989.

COSTA, Iná Camargo. Sobre o Auto dos 99\%. Onde se vê como a Universidade capricha no subdesenvolvimento. São Paulo: Cultura Vozes, v. 88, p. 114-118, 1994.

A Hora do Teatro Épico no Brasil. Rio de Janeiro: Paz e Terra, 1996.

FÁVERO, Maria de Lourdes. UNE em tempos de autoritarismo. Rio de Janeiro: Editora UFRJ, 1995.

FERNANDES, Florestan. Universidade e desenvolvimento. In: IANNI, Octavio (Org.)

Florestan Fernandes. Sociologia Crítica e Militante. São Paulo: Expressão Popular, 2004, p. 273-316.

GARCIA, Miliandre. A questão da cultura popular: as políticas culturais do CPC (Centro Popular de Cultura) da União Nacional dos Estudantes (UNE). Revista Brasileira de História (Impresso), São Paulo, v. 47, n. 47, p. 127-162, 2004.

MENDONÇA, Sonia Regina de; FONTES, Virginia Maria. História do Brasil Recente 
1964-1992. São Paulo: Ática, 1996.

OLIVEIRA, Francisco de. A Economia Brasileira: Crítica à Razão Dualista. São Paulo: Cebrap, 1972.

OLIVEIRA FILHO, Virgílio Roma. A Revolução Nacional Isebiana - H. Jaguaribe e N. W. Sodré. Estudos de Sociologia. V. 5, n. 9, 2000.

PAULA, Christiane Jalles de. Viver para a política: Gustavo Corção na crônica política brasileira (1953-1961). (Seminário). II Seminário de Sociologia da Cultura e da Imagem, UFRJ, 2005.

PISCATOR, Erwin. Teatro Político. Rio de Janeiro: Civilização Brasileira, 1968.

RIDENTI, Marcelo. Ação Popular: cristianismo e marxismo. In: Reis Filho, Daniel Aarão e Ridenti, Marcelo (orgs.). História do marxismo no Brasil, 5. Partidos e organizações dos anos 20 aos 60. Campinas: Editora da UNICAMP, 2002, p.213-282. ROSENFELD, Anatol. O Teatro Épico. São Paulo: Buriti, 1965.

SIMALTY-TEMERSON, Lê Theatre D'Agitation em Pologne. In: Le Théâtre d'agitprop de 1917 à 1932. Lausanne : Editora La Cité/L'Age D'Homme. 1978. 